\title{
Determination of genetic divergence in pointed gourd by principal component and non-hierarchical euclidean cluster analysis
}

\section{Priyanka Verma, S. K. Maurya, Hridesh Yadav and Ankit Panchbhaiya}

Department of Vegetable Science, College of Agriculture, G.B. Pant University of Agriculture and Technology, Pantnagar- 263145, Udham Singh Nagar (Uttarakhand), INDIA

*Corresponding author. E-mail: priyankavrm10@gmail.com

Received: December 31, 2016; Revised received: April 26, 2017; Accepted: November 3, 2017

\begin{abstract}
The present investigation was carried out at Vegetable Research Centre, Pantnagar to estimate the genetic divergence using Mahalanobis $D^{2}$ statistics for twelve characters on 35 genotypes of pointed gourd. Cluster analysis and principal component analysis (PCA) were used to identify the most discerning trait responsible for greater variability in the lines and on the basis of mean performance, genotypes were classified into different groups. Five principal components (PC) have been extracted using the mean performance of the genotypes and 83.23 per cent variation is yielded by the first five principal components, among them high mean positive value or higher weight age was obtained was obtained for days to first female flower anthesis and days to first fruit harvest among all the vectors, indicates that these traits are important component of genetic divergence in pointed gourd. Non- hierarchical Euclidean cluster analysis grouped the genotypes into seven clusters and the highest number of genotypes were found in cluster number IV i.e. eleven whereas maximum inter-cluster distance was found between the cluster $\mathrm{III}$ and $\mathrm{VI}$ i.e. 74.250, it indicates that a wide range of genetic divergence is present between the genotypes present among these two clusters. And as per contribution toward total divergence, traits like fruit yield per hectare and number of fruit per plant contributed $92.64 \%$ toward total divergence. The high diversity found in the genotypes showed its great potential for improving qualitative as well as quantitative traits in pointed gourd.
\end{abstract}

Keywords: Divergence, Non-hierarchical cluster, PCA, Principal component analysis, Pointed gourd

\section{INTRODUCTION}

The perennial pointed gourd (Trichosanthes dioica Roxb.) $2 n=2 x=22$, originates in the old world, most probably in India and it is a highly nutritious crop and occupied a desirable position during summer and rainy seasons in the vegetable markets of our country. It is locally known as parwal, parmal, panal and green potato and widely cultivated in eastern Uttar Pradesh, Bihar, West Bengal, Assam and lesser part in Orissa, Maharashtra and Gujarat. In India, 22 species of Trichosanthes has been chronicled among which only two species namely Trichosanthes anguina and Trichosanthes dioica are cultivated as vegetable. Well established dioecism, perennial nature and vegetative means of propagation make pointed gourd morphologically distinct from other cucurbitaceous species and being having dioecious flowering habit it is cultivated as an annual crop through vegetative propagation moreover by vine cuttings or root suckers. It has higher nutrient content than any other cucurbits (Pandit and Hazra, 2008) and its fruits are mainly rich in vitamin A (153 IU), vitamin C (2\%), protein ( $2 \%)$, fat $(0.3 \%)$ per 100 $\mathrm{g}$ of edible portion. Unremitting vegetative propagation and astute selection in pointed gourds leads to a considerable variability with respect to different forms and number of fruits. This signifies that genetic diversity is of foremost importance in breeding programs, since they consent the identification of suitable parents for hybrids development having greater heterotic upshot along with greater segregation in recombination, allowing the appearance of transgressive genotypes (Cruz and Carneiro, 2003). Genetic improvement in any crop depends on amount of variability generate in it for further selection of parents for hybridization programme, in this context the study on genetic divergence is of vital importance for any plant breeding programme, aims at genetic improvement (Srinivas et al., 2016). Cluster analysis is a multivariate method for assemblage the individuals according to their traits and classifying the individuals with similar types into the same group or cluster (Hair et al., 1995). The knowledge of genetic distance between parents is obligatory in order to get maximum benefit from transgressive segregants (Khodadabi et al., 2011). Hybrids shaped from distantly related parents have expected to exhibit higher heterosis and should minimize the inherent field genetic vulnerability than those from closely related parents (Ramanujam et al., 1974). The principal component analysis interpret that the traits were influential in genotype differentiation (Kovacic, 1994). And it enables easier understanding of impacts and 
connections among different traits by finding and explaining them. Principal component and cluster analyses were performed to establish phenotypic similarities between genotypes, which could be useful for sampling in ensuing studies. The knowledge of characters influencing divergence is important for a breeder to plan a successful breeding programme. Thus, the present study was undertaken to assess the genetic diversity in 35 genotypes of pointed gourd and to identify suitable parent for a successful breeding programme in this crop.

\section{MATERIALS AND METHODS}

The present experiment was carried out at experimental field of Vegetable Research Centre of Govind Ballabh Pant University of Agriculture and Technology, Pantnagar, Udham Singh Nagar, Uttarakhand, India during summer - rainy season of 2014 to estimate the genetic divergence in pointed gourd. The experiment comprised of thirty five germplasm lines of pointed gourd along with two checks (Kashi Alankar and Rajendra Parwal-1) which was laid out in augmented block design II. Each pointed gourd accession were considered as individual treatment so, there were 35 treatments in experiment which was laid out at a spacing of $2.5 \times 1.0 \mathrm{~m}$. All the genotypes were collected from different parts of India mainly from Uttar Pradesh and Bihar and preserved at Pantnagar. For studying different genetic parameters and inter relationships, twelve characters were taken into contemplation. Genetic diversity was studied by Mahalanobis (1936) generalized distance (D2) also called as nonhierarchical Euclidean cluster analysis later described by Beale (1969). This method is used to determine the differences and similarities among the genotypes and Euclidean distance which is distance measured is the parameter used to reflect the differences existing among the genotypes (Kendall, 1980). Principal component analysis (PCA) method which is a multivariate technique was developed by Hotelling (1933) after its original concept given by Pearson (1901).

\section{RESULTS AND DISCUSSION}

Pointed gourd with a dioecious morphology, result in opting outcrossing method which become a reason to increase variability in this crop. Principal component analysis reflects the importance of the largest contributor to the total variation at each axis of differentiation (Sharma, 1998) and the eigen values calculated are often used to determine how many factors to retain. The sum of the eigen values is generally equal to the number of variables. Therefore, in this analysis the first factor retains the information contained in (4.11) of the original variables. Quantification of variability from genetic point of view is very little that the first principal axis largely accounted for the variation among the genotype i.e. 31.618 per cent variation of total variation followed by second to fifth components which accounted 20.306, 13.824, 10.311 and 7.179 per cent of total variation presented among 35 pointed gourd genotypes, respectively. Approximately, 83.239 per cent variation is yielded by the first five principal components suggesting a considerable diversity present among the characters and rest of the component are not painstaking. The eigen values and associated cumulative percentage of variation explained by eigen vectors have been presented in Table 1 and Fig.1 which presents the cattle scree graph for variation explained by various principal components. The present research work is supported by the studies done by Janaki et al. (2016) in chilli. Singh et al.(2013) has found that the among all principal components, first two principal component accessions accounted $59.29 \%$ of the variance among 38 accessions in onion by sing XL STAT-2011 and SAS 9.2 software SAS Institute (2011) .

According to Kumar et al., 2010 "the eigen vector of the five principal components has been scaled in way that the largest element in each vector as unity was interpreted as the relative weight given to the variable in each component". The results of Canonical vector analyses revealed that in vector I, the important char-

Table 1. Eigen vector, Eigen root and associated variation for principal component in pointed gourd based on economic traits.

\begin{tabular}{lllllll}
\hline SI. No. & Characters & PCA I & PCA II & PCA III & PCA IV & PCA V \\
\hline 1 & Days of First Female Flower anthesis & 0.150 & 0.494 & 0.001 & 0.252 & 0.285 \\
2 & Node number to First Female Flower & 0.192 & 0.272 & -0.214 & -0.236 & -0.100 \\
3 & Days of First Fruit harvesting & 0.114 & 0.517 & 0.001 & 0.320 & 0.265 \\
4 & Fruit Length (cm) & -0.016 & 0.449 & -0.156 & -0.286 & -0.276 \\
5 & Fruit Diameter (cm) & -0.069 & 0.075 & 0.581 & 0.207 & -0.209 \\
6 & Fruit Weight (g) & -0.211 & 0.323 & 0.392 & -0.317 & -0.183 \\
7 & Inter-nodal Length (cm) & 0.276 & -0.134 & 0.092 & -0.026 & -0.542 \\
8 & Vine Length (m) & -0.474 & 0.099 & -0.038 & -0.001 & -0.066 \\
9 & Number of fruits per Plant & -0.324 & -0.168 & -0.367 & 0.351 & 0.045 \\
10 & Fruit Yield (q/ha) & -0.481 & 0.093 & -0.005 & 0.031 & -0.076 \\
11 & 100 Seed Weight & -0.099 & -0.107 & 0.094 & -0.627 & 0.552 \\
12 & Number of seeds per fruit & -0.002 & -0.142 & 0.534 & 0.184 & 0.259 \\
& Eigen value (root) & 4.110 & 2.640 & 1.797 & 1.340 & 0.933 \\
& \% Variation & 31.618 & 20.306 & 13.824 & 10.311 & 7.179 \\
& Cumulative variation & 31.618 & 51.925 & 65.749 & 76.060 & 83.239 \\
\hline
\end{tabular}


Table 2. Distributing pattern of 35 genotypes of pointed gourd into seven clusters.

\begin{tabular}{|c|c|c|c|}
\hline Cluster number & Number of genotypes & Genotypes & Place of collection \\
\hline \multirow{6}{*}{ I } & \multirow{6}{*}{6} & PPG-34 & Gaura, Varanasi \\
\hline & & PPG-29 & Fateganjpurbi, bareily \\
\hline & & PPG-14 & IIVR, Varanasi \\
\hline & & PPG-26 and PPG-25 & Aashapur, Varanasi \\
\hline & & Rajendra Parwal-1 & Samastipur, Bihar \\
\hline & & PPG-15 & Gopalpur, Varanasi \\
\hline \multirow{4}{*}{ II } & \multirow{4}{*}{5} & Kashi Alankar & IIVR, Varanasi \\
\hline & & PPG-1 & Jagdishpur, Faizabad \\
\hline & & PPG-16 & Allahabad, UP \\
\hline & & PPG-10 & Diara, Samastipur \\
\hline \multirow[t]{2}{*}{ III } & \multirow[t]{2}{*}{2} & PPG-31 and PPG-32 & Gopalpur,Varanasi \\
\hline & & PPG-3 & Sarav, Baldiray, Sultanpur \\
\hline \multirow{8}{*}{ IV } & \multirow{8}{*}{11} & PPG-28 & Gopalpur, Varanasi \\
\hline & & PPG-19 & Fatehganjpurbi, Bareilly \\
\hline & & PPG-22 and PPG-23 & Gaura, Varanasi \\
\hline & & PPG-21 and PPG-13 & IIVR, Varanasi \\
\hline & & PPG-4 & Bahadurganj, Faizabad \\
\hline & & PPG-12 & Diara, Samastipur \\
\hline & & PPG-27 & Aashapur, Varanasi \\
\hline & & PPG-33 & Gopalpur, Varanasi \\
\hline \multirow{5}{*}{$\mathrm{V}$} & \multirow{5}{*}{7} & PPG-35 & Allahabad, UP \\
\hline & & PPG-24 and PPG-9 & Gaura, Varanasi \\
\hline & & PPG-7 & Digra, Samastipur \\
\hline & & PPG-6 & Kumarganj, Faizabad \\
\hline & & PPG-17 and PPG-30 & Fatehpurganjpurbi, Bareily \\
\hline \multirow{3}{*}{ VI } & \multirow{3}{*}{3} & PPG-36 & $\begin{array}{l}\text { Allahabad, UP } \\
\text { Kalyanpur, Samastipur }\end{array}$ \\
\hline & & PPG-8 & Kalyanpur, Samastipur \\
\hline & & PPG-18 & Fatehganjpurbi, Bareilly \\
\hline \multirow{3}{*}{ VII } & \multirow{3}{*}{3} & PPG-20 & Allahabad, UP \\
\hline & & PPG-5 & Kumarganj, Faizabad \\
\hline & & PPG-2 & MatethinBujarg, Faizabad \\
\hline
\end{tabular}

Table 3. Average distance of intra and inter-cluster centroids.

\begin{tabular}{llllllll}
\hline CLUSTER & I & II & III & IV & V & VI & VII \\
\hline I & 8.326 & 21.388 & 38.047 & 25.656 & 20.77 & 34.067 & 32.907 \\
II & & 9.888 & 20.612 & 33.608 & 22.308 & 55.774 & 41.974 \\
III & & 9.091 & 30.717 & 34.425 & 74.258 & 43.014 \\
IV & & & 11.846 & 17.508 & 28.619 & 30.236 \\
V & & & & 13.062 & 27.065 & 30.291 \\
VI & & & & & & 25.878 & 50.870 \\
VII & & & & & & & 31.608 \\
\hline
\end{tabular}

Table 4. Cluster mean for different economic traits in pointed gourd genotypes.

\begin{tabular}{lllllllll}
\hline S. No. & Characters & I & II & III & IV & V & VI & VII \\
\hline $\mathbf{1}$ & Days of first female flower & 65.25 & 48.81 & 25.48 & 49.172 & 59.66 & 66.89 & 61.98 \\
$\mathbf{2}$ & Node number to first female flower & 12.50 & 8.48 & 62.04 & 8.105 & 3.78 & 36.27 & 115.61 \\
$\mathbf{3}$ & Days of first fruit harvesting & 73.89 & 62.04 & 45.22 & 59.300 & 68.59 & 75.52 & 68.89 \\
$\mathbf{4}$ & Fruit length (cm) & 9.68 & 8.10 & 7.09 & 7.925 & 7.70 & 9.01 & 7.09 \\
$\mathbf{5}$ & Fruit diameter (cm) & 3.16 & 3.78 & 3.20 & 3.114 & 3.67 & 3.56 & 2.97 \\
$\mathbf{6}$ & Mean fruit weight (g) & 37.20 & 39.27 & 29.24 & 27.408 & 30.82 & 35.28 & 17.56 \\
$\mathbf{7}$ & Inter-nodal length (cm) & 9.75 & 8.29 & 9.18 & 12.603 & 10.81 & 11.42 & 8.55 \\
$\mathbf{8}$ & Vine length (m) & 7.33 & 8.19 & 7.72 & 5.445 & 6.13 & 4.38 & 5.94 \\
$\mathbf{9}$ & Number of fruits per plant & 99.19 & 115.61 & 137.10 & 82.793 & 93.38 & 42.99 & 145.95 \\
$\mathbf{1 0}$ & Fruit yield (q/ha) & 146.38 & 180.72 & 160.01 & 88.677 & 112.25 & 58.65 & 102.30 \\
$\mathbf{1 1}$ & 100 seed weight (g) & 10.82 & 9.73 & 12.51 & 10.160 & 9.39 & 8.97 & 7.86 \\
$\mathbf{1 2}$ & Number of seeds per fruit & 12.67 & 23.40 & 18.89 & 17.893 & 25.50 & 21.94 & 11.02 \\
\hline
\end{tabular}


Table 5. Contribution of different characters towards genetic divergence.

\begin{tabular}{llll}
\hline SI. No. & Source & Number of first rank & Contribution \% \\
\hline $\mathbf{1}$ & Days of first female flower anthesis & 25 & 3.75 \\
$\mathbf{2}$ & Node number to first female flower & 1 & 0.15 \\
$\mathbf{3}$ & Days of first fruit harvesting & 7 & 1.05 \\
$\mathbf{4}$ & Fruit length (cm) & 0 & 0.00 \\
$\mathbf{5}$ & Fruit diameter (cm) & 0 & 0.00 \\
$\mathbf{6}$ & Fruit weight $(\mathrm{g})$ & 0 & 0.00 \\
$\mathbf{7}$ & Inter-nodal length (cm) & 0 & 0.00 \\
$\mathbf{8}$ & Vine length (m) & 0 & 0.00 \\
$\mathbf{9}$ & Number of fruit per plant & 202 & 30.33 \\
$\mathbf{1 0}$ & Fruit yield (q/ha) & 415 & 62.31 \\
$\mathbf{1 1}$ & 100 seed weight (g) & 0 & 0.00 \\
$\mathbf{1 2}$ & Number of seeds per fruit & 16 & 2.40 \\
\hline
\end{tabular}

acters responsible for genetic divergence were days to first female flower anthesis, days to first fruit harvesting, node number to first female flower and internodal length. In vector II, days to first female flower anthesis, days to first fruit harvest and fruit length exhibited high rate. The third principal component exhibited high positive weight to fruit diameter followed seed per fruit and fruit weight in the major axis of differentiation and so on for principal vector fourth and fifth (Table.1).The role of days to first female flower anthesis and days to first fruit harvest among all the vectors indicated these traits are important component of genetic divergence in pointed gourd genotypes. Negative values mainly in first two vectors for number of fruits per plant, seeds per fruit and 100 seed weight indicated its lowest contribution toward total divergence. Hence, considerable emphasis should be given on these traits to increase fruit yield in pointed gourd. This partly agrees with results by Nwangburuka (2010) in okra that days to flowering, fresh pod width, mature pod width, fresh pod length, pod weight per plant, seeds per pod, and seed weight per plant were relatively high in the first four principal axes confirming the major contributions of these traits to seed yield in okra. The traits that exhibited strong and positive association with yield include days to pod initiation, days to harvesting, plant height, pod length, hundred seed weight, ratio of seed length to width, stem number per plant

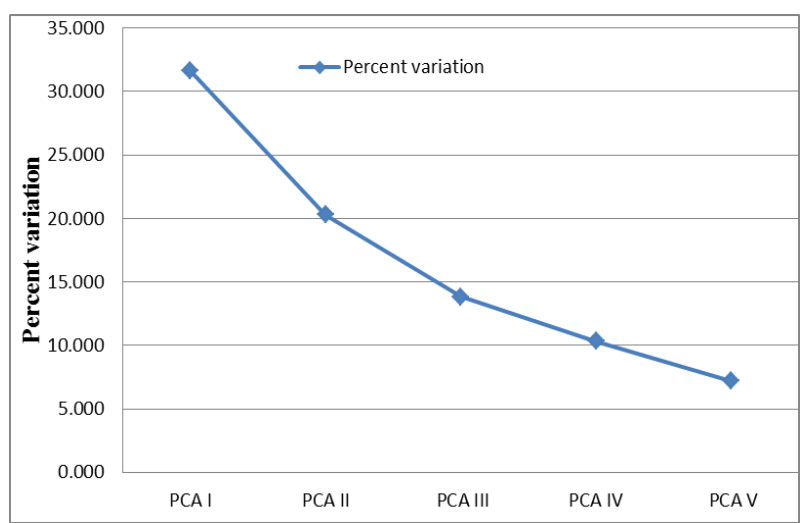

Fig. 1. Cattel scree graph for \% variation for principal component based on yield attributing traits in pointed gourd. and seed number per stem could be used as selection criteria for improving faba bean (Sharifi and Aminpana, 2014), Fruit weight, seeds per fruit and fruit weight per plant contributed maximum to the total divergence (Khan et al., 2008).

Non-hierarchical clustering was calculated using covariance matrix and accordingly, 35 genotypes of pointed gourd were grouped into seven different clusters. Based on the distributing pattern of genotypes, highest number of cluster was found in cluster number IV i.e eleven followed by cluster number $\mathrm{V}$ having seven genotypes, then cluster I with six genotypes and cluster II having five genotypes. However, cluster VI and VII have equal number of genotype i.e. three in each. Minimum number of genotypes was found in cluster number III i.e. PPG-31 and PPG-32. These clusters formed using covariance matrix are regarded as useful source of genotypes/gene for different traits. Similar conclusion were given Khan et al.,(2008) in pointed gourd with maximum 8 genotypes in cluster $\mathrm{V}$, Iqbal e al., (2014) in tomato with maximum genotype i.e. 22 in cluster I. Sultana, et al.,(2015) estimated that by using $\mathrm{D}^{2}$ clustering method, 22 genotypes of Ash gourd were grouped into five different clusters with cluster IV containing the maximum number of genotypes i.e. 7 whereas cluster I contained least number having only one genotypes. The clustering pattern of genotypes in this study clearly indicates that, geno-

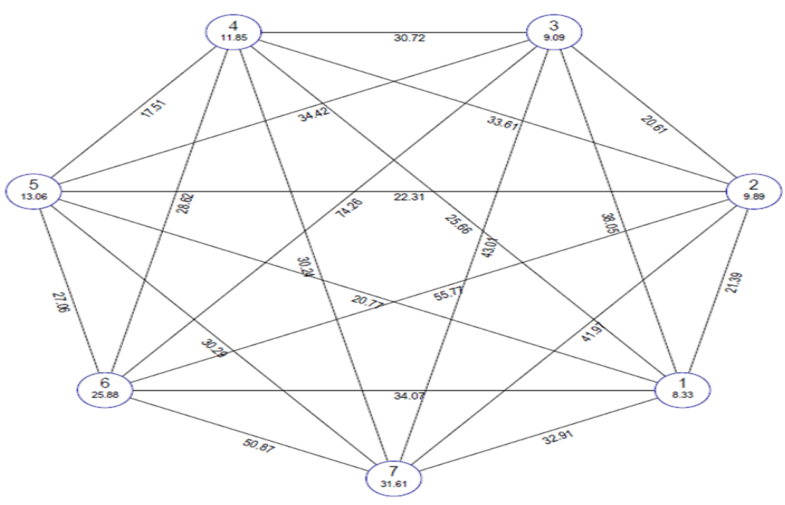

Fig. 2. Average distance of intra and inter-cluster centroids based on various traits in 35 pointed gourd genotypes (summer-rainy season 2014). 


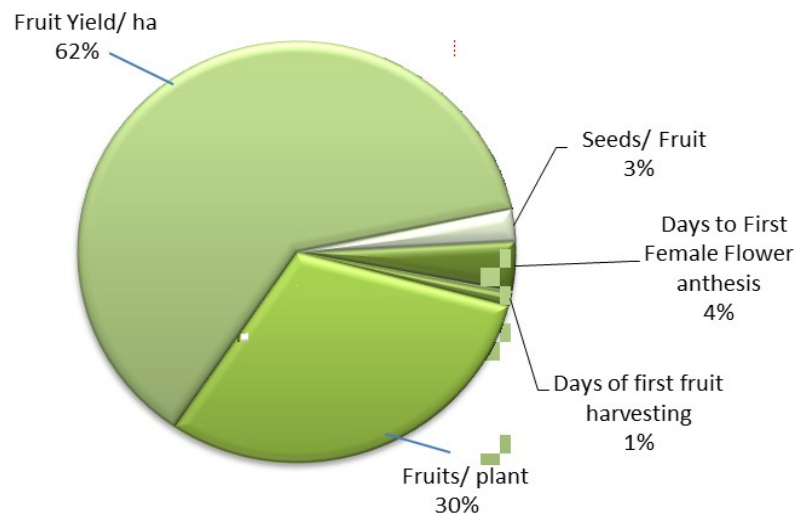

Fig. 3. Contribution percent of different characters towards genetic divergence.

types collected from different places where unbiasly and invariably placed in same clusters which mean that cluster are formed having heterogeneous origin showing a strong non- parallelism between genetic and geographical diversity. This is in agreement with Syed et al., (2012) who reported that clustering of chickpea genotypes did not follow geographical distribution. The genotypes with their respective places of origin and clusters have been presented in (Table 2).

According to Huque et al., (2012) the magnitude of the intra cluster distances were not always proportional to the number of genotypes in the clusters. In background of it, in present study maximum intra-cluster distance was noted in cluster VII (31.608) followed by cluster VI (25.878), cluster V (13.062), cluster IV (11.846) while minimum intra-cluster distance was recorded in cluster I (8.326). Distribution of genotypes in each cluster is presented in Table 3 and fig. 2. This result was in agreement with Gaffar(2008), he stated that the highest intra cluster distance was noticed for the cluster II (0.999) and the lowest for the cluster IV (0.439) when the genotypes of ridge gourd were grouped into five clusters. According to Janki et al., (2016), highest inter cluster distance was observed between clusters IV and VIII (4139.41) whereas the lowest was observed between clusters I and III (117.25) in chilli.

Ghaderi et al., (1984) quoted that " increasing parental distance implies a great number of contrasting alleles at the desired loci, and to the extent that these loci recombine in the F2 and F3 generation following a cross of distantly related parents, the greater will be the opportunities for the effective selection for yield factors". So, in light of that in present study maximum inter-cluster distance was calculated between cluster VI and III (74.250) so more emphasis should be given on these clusters in selecting inbreds for crossing in hybridization programmes. Average inter-cluster distances were higher than the average intra-cluster distances suggesting wider genetic diversity among the genotypes within cluster. The cluster means for all the characters are given in Table 4 . In accordance with cluster mean value, cluster I has highest mean value for fruit length (9.68) and cluster II has the highest mean value for fruit diameter (3.78), mean fruit weight (39.27), fruit yield per hectare (180.72) and vine length (8.19). While cluster III, IV, V has maximum cluster mean value for 100 seed weight (12.51), internodal length (12.60) and seeds per fruit (25.50) respectively. In cluster VI highest mean value was observed for days to first female flower anthesis (66.89), node number to first female flower (15.57) and days to first fruit harvest (75.52) and cluster VII has maximum mean value for only one character i.e. number of fruits per plant (145.95). From the results it is concluded that genotypes for fruit length from cluster I, fruit diameter, mean fruit weight and fruit per hectare from cluster II and genotypes for number of fruits per plant should be selected as parents for hybridization programme. The present study was in agreement with the findings of Pan et al.(2009) who concluded that to develop early varieties, selection from Cluster III will be more effective and for high yielding varieties having high fresh seed weight, selection from Cluster $\mathrm{V}$ in lablab bean. Sultana et al. (2015) in pumpkin has found that cluster I contained the highest mean values for fruit length (74.40), fruit breadth (35.00) and fruits/ plant (7.15) whereas cluster II contained the highest mean values for days to first male (85.83)and female flowering (86.83) so fruit length, fruit breadth, fruits per plant and number of male flowers/plant were the important components of genetic divergence in the studied materials.

The contribution of each trait to total divergence is presented in Table 5 and figure 3. Among the traits studied, fruit yield ( $\mathrm{q} / \mathrm{ha}$ ) contributed maximum divergence $(62.31 \%)$ followed by number of fruit per plant $(30.33 \%)$, days to first female flower anthesis $(3.75 \%)$, number of seed per fruit $(2.40 \%)$, days to first fruit harvesting $(1.05 \%)$ and node number to first female flower $(0.15 \%)$. The traits viz., fruit yield per hectare and number of fruit per plant contributed $92.64 \%$ toward total divergence. Hence, these characters should be given importance during hybridization and selection in the segregating population. These results are close conformity with the findings of Devi and Marriappam (2014) in snake gourd, that the traits like average fruit weight days to first female flower appearance, yield per hectare, fruit length contributed $98.70 \%$ towards total divergence.

\section{Conclusion}

While studying the divergence in pointed gourd genotypes thereby underlining the fact that the hybridization of genotypes of different cluster with common male parent is necessary for the development of desirable genotypes. In present study, maximum intercluster distance was observed between cluster VI and III (74.250) so genotypes under these two clus- 
ters should be given more emphasis in selecting inbreds for crossing in hybridization programmes. Based on the performance of the best genotype within the clusters, there may be directly selected or may be used as potential parents in hybridization programme. For earliness PPG-31 and PPG-32 from cluster I should be selected and for high yield per hectare, fruit weight and fruit diameter, genotypes like PPG-1, PPG15, and PPG-16 should be selected from cluster II.

\section{REFERENCES}

Afroze, F., M. G. Rasul, Islam, A.K.M.A., Mian, M.A.K. and Hossain, T. (2007). Genetic divergence in ash gourd (BenincasahispidaThunb.).Bangladesh $\mathrm{J} . \mathrm{Pl}$. Breed. Genet., 20(1): 19-24.

Beale, E.M.L. (1969).Euclidean cluster analysis. $37^{\text {th }}$ session of Int Stat Inst, UK.

Cruz, C. D. and Carneiro, P.C. (2003). Modelosbiométricosaplicadosaomelhoramento genetic diversity.Viçosa (MG): UFV, Imprensa University. 2(1).

Devi, N.D. and Mariappan, S. (2014). Studies on genetic diversity in snake gourd (TrichosanthesanguinaL.). Universal Journal of Agricultural research.(1): 1-5.

Iqbal, Q., Saleem, M.Y., Hameed, A. and Asghar, M. (2014). Assessment of genetic divergence in tomato through agglomerative hierarchical clustering and principal component analysis. Pak. J. Bot., 46(5): 1865$1870 \mathrm{Z}$

Gaffar, A. (2008). Characterization and genetic diversity of sponge gourd (Luffa cylindrica L.).M.Sci. Thesis submitted to Sher-e- Bangla Agricultural University, Dhaka. India. pp. 88-90.

Ghaderi, A., Adams, M.W. andNassib, A.M. (1984).Relationship between genetic distance and heterosis for yield and morphological traits in dry edible bean and faba bean.Crop Sci. 24:37-42.

Hair, J.R., R.E. Anderson, R.L. Tatham, and W.C. Black. (1995). Multivariate data analysis with readings. 4th edition, Prentice-Hall, Englewood Cliffs, NJ.

Hotelling, H. (1933). Analysis of complex of statistical variables into principal components. Journal of Educational pshycology, 24: 417-441.

Huque, A.K.M.H., Hossain, M.K., Alam, N., Hasanuzzaman, M. and Biswas, B.K.(2012). Genetic divergence in yardlong bean (Vignaunguiculata (L.) walp. Ssp. Sesquipedalisverdc). Bangladesh J. Bot., 41(1):61-69.

Janaki, M., Naram Naidu, L., VenkataRamana, C. \&Paratpara Rao, M. (2016).Genetic divergence among chilli (Capsicum annuum 1.) Genotypes based on quantitative and qualitative traits. I.J.S.N.7.(1): 181-189.

Kendall, M. (1980).Multivariate Analysis (Second Edition).Charles Griffin and Co London.

Khan, A.S.M.R., Rabbani, M.G., Siddique, M.A.and Hossain, M.I. (2008). Study on genetic diversity of pointed gourd using morphological characters. Bangladesh $J$. Agril. Res. 33(3): 607-616.

Khodadabi, M., Fotokian, M.H. and Miransari, M. (2011). Genetic diversity of wheat genotypes based on cluster and principal component analysis for breeding strategies. Australian J. Crop Sci. 5.(1): 17-24.

Kovacic, Z. (1994). Multivariate analysis.Faculty of Economics.University of Belgrade.(In Serbian).P. 293.

Kumar, S.,Marappa, N. And Govindaraj.M.(2010). Classification of new germplasm and advanced breeding lines of groundnut (Arachishypogaea L.) through principal component analysis. Leg. Res. 33: 242-248.

Mahalanobis, P.C. (1936). On the Generalized Distance in Statistics.Proc. Natl. Scence. India B. (2): 49- 55.

Nwangburuka, C. C. (2010). Morphological characterization and genetic studies in okra Abelmoschusesculentus (L.) Moench. Ph.D. Thesis submitted to Federal University of Agriculture, Abeokuta, Nigeria.

Nwofia, J. E., Amajuoyi, A.N. andMbah, E.U. (2015). Response of three cucumber varieties (CucumussativusL.) to planting season and NPK fertilizer rates in lowland humid tropics, sex expressions, yield and interrelationship between yield and associated traits. International Journal of Agriculture and Forestry. 5(1): 30-37.

Pan, R.S., Singh, A.K., Kumar, S., and Rai, M. (2009) Studies on genetic divergence in lablab bean through principal analysis. Ind J Hort. 66: 483-487.

Pandit, M.K. and Hazra, P. (2008).Pointed gourd. In: Rana, M.K. ed. Scientific cultivation of vegetables. New Delhi, Kalyani Publication. pp. 218-228.

Pearson, K. (1901). On lines and planes of closest fit to systems of point in space. Philosophical Magazine, (2): 559 -572 .

Ramanujam, S., Tiwary, A.S. and Mehra, R.B. (1974).Genetic divergence and hybrid performance in mungbean.Theor. Appl. Genet. 44.(5): 211-214.

SAS Institute (2011). SAS enterprise guide, Version 9.2. SAS Inst., Cary, NC, USA.

Sharma, J.R. (1998). Statistical and biometrical techniques in plant breeding. New Age International, New Delhi.

Sharifi, P. and Aminpana, H. (2014).A study on the genetic variation in some of faba bean genotypes using multivariate statistical techniques. Trop. Agric. 91(2):87-97.

Singh, S. R., Ahmed, N., Lal, S., Ganie, S. A., Amin, M., Jan, N. and Amin, A. (2013).Determination of genetic diversity in onion (Allium cepaL.) by multivariate analysis under long day conditions.African Journal of Agricultural Research.8.(45): 5599-5606.

Srinivas, J., Kale, V. S., Nagre, P.K. and Meshram, M. (2016). Genetic divergence studies in cowpea. International Journal of Agricultural Science and Research. 6. (3): 97-104.

Sultana, S., Kawochar, M.A., Naznin, S., Raihan, H. and Mahmud, F.(2015). Genetic Divergence in Pumpkin (Cucurbita moschata L.)Genotypes.Bangladesh J. Agril.Res.40.(4): 683-692.

Syed, M.A., Islam, M.R., Alam, M.M. and Amin, M.N. (2012). Genetic divergence in chickpea (Cicer arietinum L.). Bangladesh journal of agricultural research, 37: 129-136.

Yadav, H., Maurya, S. K., and Bhatt, L. (2016).Genetic Divergence in Ridge Gourd through Principal Component and Non-Hierarchical Cluster Analysis.Environment \& Ecology. 34(1A): 334-340. 